\title{
Deteksi Dini Anemia pada Remaja di Pulau Nguan Kecamatan Galang Kota Batam Tahun 2020
}

\author{
Desi Pramita Sari ${ }^{1}$, Suci Ridmadhanti, Roza Erda, Trisna Yuni Handayani, \\ Norma Jeepi Margiyanti, Renny Adelia Tarigan, \\ Diploma Tiga Kebidanan, Institut Kesehatan Mitra Bunda \\ chypramitha24@gmail.com
}

\begin{abstract}
ABSTRAK
Anemia merupakan suatu keadaan kadar hemoglobin $(\mathrm{Hb})$ didalam darah lebih rendah daripada nilai normal untuk kelompok orang menurut umur dan jenis kelamin. Hemoglobin adalah zat warna di dalam darah yang berfungsi mengangkut oksigen dan kerbondioksida dalam tubuh (Jayantik, 2015). Remaja perempuan rentan mengalami anemia dikarenakan terkait masalah gizi dan menstruasi. Data yang didapatkan dari Dinas Kesehatan Kepulauan Riau tahun 2018 menunjukkan remaja putri usia 15 - 24 tahun mengalami anemia sebanyak $38,1 \%$ dan remaja putra sebanyak 19,7\% dan data Dinas Kesehatan Kota Batam (2019) menunjukkan angka kejadian anemia remaja putri sebanyak 121 orang atau $0,10 \%$ dari jumlah remaja putri se-kota Batam. Pulau Nguan merupakan salah satu pulau kecil di galang yang jauh dari akses fasilitas kesehatan. Di Kecamatan galang kejadian anemia remaja putri sebanyak 5 orang atau 0,2\%. Kegiatan ini bertujuan untuk mendeteksi dini terjadinya anemia pada remaja dan meningkatkan pengetahuan remaja tentang anemia.
\end{abstract}

Kata Kunci : Anemia, Remaja

\begin{abstract}
Anemia is a circumstance $(\mathrm{Hb})$ levels of hemoglobin in the blood is lower than normal for groups of people according to age and sex. Color is a substance of hemoglobin in the blood which serves transport oxygen in the body and carbondioxide (Jayantik, 2015). The girl more risky to anemia because of nutrition problem and menstruation. The department of health Riau's islands years 2018 the teenager girls age 15 - 24 year show anemia 38,1\% and teenager son show 19,7 \%. According to Department of Health Batam (2019) incidence anemia adolescent girls as many as 121 people or $0,10 \%$ of the all adolescent girls in Batam. Nguan's island is one of small island in Galang that Far access from the Pulic Health. The Incidences anemia in sub-district galang, Nguan's Island show 5 teenagers or $0,2 \%$. This event is aimed to detect early the anemia in teenager and improved their knowledge of anemia.
\end{abstract}

Key Word : Anemia, Teeneger 
Jurnal Pelayanan dan Pengabdian Masyarakat (PAMAS)

\section{PENDAHULUAN}

Anemia merupakan suatu keadaan kadar hemoglobin $(\mathrm{Hb})$ didalam darah lebih rendah dari pada nilai normal untuk kelompok orang menurut umur dan jjenis kelamin. Hemoglobin adalah zat warna didalam darah yang berfungsi mengangkut oksigen dan karbondioksida dalam tubuh ${ }^{1}$.

Remaja laki-laki maupun perempuan dalam masa pertumbuhan membutuhkan energi, protein dan zat-zat gizi lainnya yang lebih banyak dibanding dengan kelompok umur lain. Ditambahkan bila sebagian besar dari permasalahan itu diakibatkan kekurangan zat besi (anemia defisiensi besi). Anemia dikalangan remaja perempuan lebih tinggi dibanding remaja laki-laki. Pematangan seksual pada remaja menyebabkan kebutuhan zat besi meningkat, karena dibutuhkan untuk mengganti zat besi yang hilang pada saat menstruasi ${ }^{2}$. United Nations Population Fund (UNFPA) menyatakan bahwa ketika remaja perempuan diberi kesempatan untuk mengakses pendidikan dan kesehatan mereka, termasuk kesehatan reproduksi, akan menciptakan peluang bagi remaja untuk merealisasikan potensi, maka remaja dapat mengelola dengan baik masa depan diri mereka, keluarga, dan masyarakat ${ }^{3}$.

Nilai batas ambang untuk anemia menurut WHO (2015) adalah untuk umur 5-1 1 tahun $<11,5 \mathrm{~g} / \mathrm{L}, 11-14$ tahun 5 2,0 g/L, remaja diatas 15 tahun untuk anak perempuan < $12,0 \mathrm{~g} / \mathrm{L}$ dan anak laki-laki $<3,0 \mathrm{~g} / \mathrm{L}(\mathrm{WHO}, 2015)$.Anemia pada remaja putri sampai saat ini masih cukup tinggi.

Prevalensi anemia remaja dunia berkisar $40-88 \%$. Menurut WHO, angka kejadian anemia pada remaja putri di Negara berkembang sekitar $53,7 \%$ dari semua remaja putri, anemia sering menyerang remaja putri disebabkan karena keadaan stress, haid, atau terlambat makanan ${ }^{4}$.

Permasalahan gizi yang dihadapi remaja salah satunya adalah masalah anemia. Prevalensi anemia di Indonesia yaitu 21,7\%. Penderita anemia berumur 5 -14 tahun sebesar $26,4 \%$ dan penderita berumur $15-24$ tahun sebesar $18,4 \%{ }^{5}$. Penderita anemia pada remaja juga dilaporkan tinggi berdasarkan data Survei Kesehatan Rumah Tangga (SKRT) tahun 2016 dengan rincian yaitu prevalensi anemia pada remaja puteri usia 10-18 tahun sebesar $57,1 \%$, dan usia $19-45$ tahun sebesar $39,5 \%$.Pada dasarnya $23 \%$ remaja putri di Indonesia mengalami anemia alias kurang darah. Dengan jumlah remaja putri kurang lebih 21 juta, terdapat setidaknya 4,8 juta yang mengidap kekurangan jumlah sel darah merah (yang mengandung protein hemoglobin, $\mathrm{Hb}$ ). Sel ini yang memungkinkan oksigen dari jantung diangkut ke seluruh bagian tubuh ${ }^{2}$. 
Data di Kepulauan Riau remaja putri usia $15-24$ tahun mengalami anemia sebanyak $38,1 \%$, remaja putra sebanyak $19,7 \%{ }^{6}$. Data di Kota Batam menunjukkan angka kejadian anemia remaja putri sebanyak 121 orang atau $0,10 \%$ dari jumlah remaja putri sekota Batam. Di kecamatan galang kejadian anemia remaja putri sebanyak 2 orang atau $0,08 \%{ }^{7}$.

Penyebab anemia yang terjadi pad remaja antara lain : asupan nutrisi, tingkat pendidikan orang tua, tingkat ekonomi, tingkat pengetahuan tentang anemia dari remaja putri, konsumsi $\mathrm{Fe}$, dan lamanya menstruasi ${ }^{7}$.

Dampak anemia yang dialami remaja putri akan membuat remaja merasa lesu, bisa menurunkan kemampuan daya ingat sehingga prestasi akademik tidak optimal dan juga dapat berdampak lebih serius, mengingat mereka adalah para calon ibu yang akan hamil dan melahirkan bayi, sehingga memperbesar risiko kematian ibu, melahirkan bayi premature dan berat bayi lahir rendah (BBLR) ${ }^{2}$.

Dari studi pendahuluan yang dilakukan didapat masih rendahnya pengetahuan remaja tentang anemia pada remaja, penyebab terjadinya anemia, tanda dan gejala anemia, klasifikasi anemia, dan dampak anemia pada remaja.

Pulau Nguan merupakan daerah yang jauh dari akses pelayanan kesehatan dan sulit mendapatkan jaringan Internet sehingga masyrakat khususnya remaja susah untuk mendapatkan informasi tentang anemia pada remaja.

\section{METODE}

\section{a. Metode Kegiatan}

Secara umum kegiatan ini menggunakan metode pemberian edukasi secara Penyuluhan dan praktek

1. Penyuluhan dan diskusi

Kegiatan penyuluhan dan diskusi dilakukan untuk memberikan pemahaman peserta tentang anemia pada remaja, penyebab terjadinya anemia, tanda dan gejala anemia, klasifikasi anemia, dan dampak anemia pada remaja dan penanganan anemia

2. Pemeriksaan $\mathrm{Hb}$

Pemeriksaan dilakukan kepada remaja putri dengan menggunakan alat easy touch. Kgiatan ini bertujuan untuk melakukan deteksi anemia pada remaja yang dilakukan oleh dosen Program Studi Diploma Tiga Kebidanan Institut Kesehatan Mitra Bunda . 


\section{b. Prosedur dan Alat Evaluasi}

Untuk mengetahui apakah program penyuluhan dan pemeriksaan $\mathrm{Hb}$ yang dilaksanakan berjalan lancar dan berdampak positif kepada masyarakat terutama remaja putrid di Pulau Nguan, maka dibuat evaluasi meliputi:

1. Melakukan Tanya-jawab dan diskusi pengetahuan remaja mengenai anemia yang dilakukan sebelum diberikan penyuluhan guna mengetahui seberapa besar pengetahuan remaja mengenai anemia.

2. Melakukan Tanya-jawab dan diskusi serta pemberian bingkisan bagi remaja yang mampu menjawab pertanyaan-pertanyaan yang telah diberikan.

3. Memberikan leaflet kepada remaja serta keluarga agar dapat dibaca kembali tentang anemia.

4. Melakukan pemeriksaan Hb pada Remaja putri di Pulau Nguan, guna mengetahui serta mendeteksi remaja di Pulau Nguan yang mengalami anemia untuk segera diberikan penanganan.

5. Melakukan pendataan hasil pemeriksaan $\mathrm{Hb}$ yang telah dilakukan.

\section{c. Teknis Analisis Data dan Kriteria Keberhasilan Program}

Data hasil tes baik pre test maupun post test tentang penyuluhan ini dianalisis dengan teknik analisis deskriptif dan analitik

\section{d. Partisipasi Masyarakat}

Jumlah Remaja yang ikut dalam kegiatan ini adalah 25 remaja putri, panitia 5 orang dosen serta mahasiswa.

\section{e. Jenis Luaran}

Luaran dari kegiatan ini adalah adanya peningkatan pengetahuan dan pemahaman remaja tentang tentang anemia, penyebab terjadinya anemia, tanda dan gejala anemia, klasifikasi anemia, dan dampak anemia pada remaja serta meningkatnya kadar $\mathrm{Hb}$ pada remaja. Selain itu kegiatan ini dapat berjalan berkesinambungan yang dapat dislaksanakan oleh pihak terkait di masa mendatang.

\section{HASIL DAN PEMBAHASAN}

Berdasarkan kegiatan yang telah dilakukan untuk mengetahui pengetahuan remaja putri di Pulau Nguan mengenai anemia melalui Tanya-jawab yang dilakukan, dapat disimpulkan bahwa remaja putri di Pulau Nguan sudah mengetahui dan tentang definisi 
anemia, remaja sudah mengerti penyebab timbulnya anemia, mampu menyebutkan klafikasi dari anemia, beberapa dari remaja putri dapat menyebutkan apa saja tanda dan gejala anemia tersebut, serta beberapa dari remaja putri mampu menjelaskan kembali dampak apa yang didapatkan jika remaja putri mengalami anemia.

Tahapan pada kegiatan yang dilakukan selain menguji pengetahuan remaja putri dengan Tanya jawab adalah pemeriksaan Hb pada remaja di Pulau Nguan. Hasil dari pemeriksaan $\mathrm{Hb}$ pada remaja dapat dilihat melalui tabel berikut ini:

\begin{tabular}{ccc}
\hline Status Anemia & Frekuensi (n) & Presentase \\
\hline Normal & 20 & $80 \%$ \\
Anemia Ringan & 3 & $12 \%$ \\
Anemia Sedang & 2 & $8 \%$ \\
Anemia Berat & 0 & $0 \%$ \\
\hline Total & 25 & $100 \%$ \\
\hline
\end{tabular}

Berdasarkan hasil pemeriksaan yang telah dilakukan pada 25 Remaja Putri di Pulau Nguan, Kecamatan Galang dapat disimpulkan bahwa prevalensi anemia pada remaja putri di Pulau Nguan, Kecamatan Galang adalah sebanyak 3 remaja putri (12\%) mengalami anemia ringan, sebanyak 2 remaja putri (8\%) mengalami anemia sedang, sebanyak 20 remaja putri $(80 \%)$ mempunya kadar Hemoglobin $(\mathrm{Hb})$ yang normal, dan tidak ada remaja putri yang mengalami anemis berat. Berdasarkan data hasil pemeriksaan yang diperoleh dapat disimpulkan bahwa sebanyak 80\% remaja putri di Pulau Nguan, Kecamatan Galang mempunyai kadar Hemoglobin $(\mathrm{Hb})$ yang normal, hal ini dapat berkaitan dengan tingkat pengetahuan remaja mengenai anemia sehingga remaja dapat mengaplikasikannya di kehidupan sehari-hari untuk mencegah terjadinya anemia pada remaja.

\section{SIMPULAN}

Berdasarkan dari kegiatan yang dilakukan di Pulau Nguan, Kecamatan Galang, dapat disimpulkan bahwa:

1. Terjadi peningkatan pengetahuan remaja mengenai anemia pada remaja, remaja mampu menjelaskan kembali dampak yang terjadi pada remaja putri yang anemia, mampu menjelaskan tanda-gejala anemia serta klasifikasi anemia tersebut.

2. Dari hasil pemeriksaan yang dilakukan didapat 2 orang remaja putri $(8 \%)$ dengan Anemia sedang, 3 orang remaja putri (12\%) dengan anemia ringan dan 20 orang remaja 


\section{Jurnal Pelayanan dan Pengabdian Masyarakat (PAMAS)}

putri (80\%) dengan kadar $\mathrm{Hb}$ normal. Pengetahuan remaja putri di pulau Nguan Kecamatan Galang sudah meningkat dan diharapkan remaja putri bisa mempertahankan kadar Hbnya .

3. Dari kegiatan yang telah dilakukan di Pulau Nguan, Kecamatan Galang masih perlu adanya tenaga kesehatan yang datang ke pulau tersebut untuk melakukan pemeriksaan Hemoglobin $(\mathrm{Hb})$ secara berkala, sehingga jika para remaja putri yang mengalami anemia untuk segera ditangani dengan pemberian Tabet Fe dan mengkonsumsi tabet FE sesuai anjuran seta makan-makanan yang mengandung gizi seimbang, sehingga kadar Hemoglobin $(\mathrm{Hb})$ pada remaja tersebut bisa kembali normal.

\section{Dokumentasi Kegiatan}
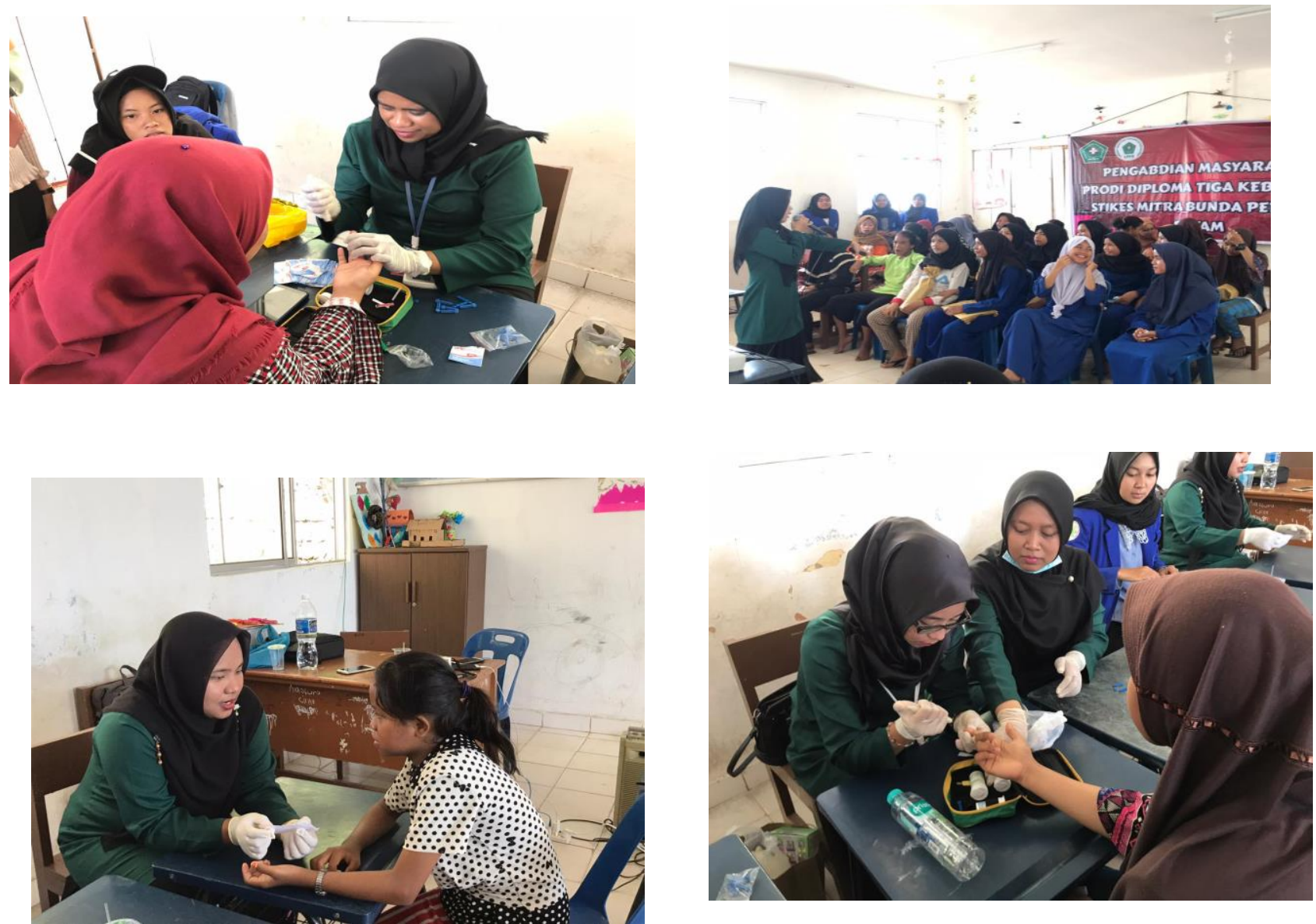


\section{DAFTAR PUSTAKA}

Redeer, Martin, Griffin, K. 2012. Keperawatan Maternitas Kesehatan Wanita, Bayi dan Keluarga Volume2 Edisi18. Jakarta : EGC.

Briawan,D. 2013. Anemia Masalah Gizi pada Remaja Wanita. Jakarta : EGC.

BKKBN. 2018. Kesehatan Reproduksi Wanita. Jakarta

WHO. 2018. Iron Deficiency Anemia Assessment, Prevention, and Control.

Kementerian Kesehatan. 2018. Profil Kesehatan Indonesia. Jakarta

Dinas Kesehatan Kepulauan Riau. 2018. Profil Kesehatan Kepulauan Riau

Amudha, M. 2016. Prevalence of anemia among adolescent girls : A cross sectional exploratory study. International Journal of Applied Research 2016; 2 (3) : 630632

Arsiyanti, Hadju,V., \& Nontji, W. 2014. Faktor Risiko Anemia Pada Remaja Putri Di Kecamatan Bontoramba Kabupaten Jeneponto. Dinas Kesehatan Kota Kendari Bagian Gizi Fakultas Keseahatan Masyarakat Universitas Hasanuddin

Balci, Y.I., Karabulut, A., Gurses, D., \& Covut, I.E. 2012. Prevalence and Risk Factors of Anemia among Adolescents in Denizli, Turkey. Iran JPediatr. 22 (1).

Bhanushali, M. M, Shirode, A.R, Joshi,Y.M, \& Kadam, V.J. 2011. An Intervention On Iron Deficiency Anemia And Change In Dietary Behaviour

Fauziah, D., Nurlina \& Korneliani, K. 2012. Hubungan Antara Pola Menstruasi dan Konsumsi Zat Besi Dengan Kejadian Anemia Pada Remaja Putri di SMA Informatika Ciamis. Program Studi Epidemiologi Dan Penyakit Tropik Fakultas IImu Kesehatan Universitas Siliwangi Tasikmalaya

Adriani, M., \&Wirjatmadi, B. 2012. Peran Gizi Dalam Status Kehidupan. Jakarta : Kencana Prenada Media Group

Ambarwati, F.R. 2012. Gizi dan Kesehatan Reproduksi. Yogyakarta : Cakrawala Ilmu Amudha,M. 2016. Prevalence of anemia among adolescent girls : A cross sectional Hakta,I .M. 2013. Hematologi Klinik Ringkas. Jakarta : EGC 
Jurnal Pelayanan dan Pengabdian Masyarakat (PAMAS)

Chauhan, A., Sandeepkumar, C.,\& Bala,D.V. 2016. International Journal of Current Research and Modern Education (IJCRME). Knowledge, Attitude, And Practices Of Adolescent Girls Towards Iron Deficiency Anemia,1(2) 
Jurnal Pelayanan dan Pengabdian Masyarakat (PAMAS) 